\title{
Improving Corrosion Resistance of Al through Sever Plastic Deformation 2-under Accelerated Condition
}

\author{
A. E. El Meleigy ${ }^{(1)}$, M. R. Ebrahim ${ }^{(2)}$, Sh. E. Abd El \\ Hamid $^{(1)}$ and A. A. EI Warraky ${ }^{(1)}$ \\ (1) Department of Physical Chemistry and (2) Department of \\ Solid State Physics, Metal Physics Lab., N. R. C., Dokki, Giza, \\ PO. 12622, Egypt.
}

\begin{abstract}
T HE CORROSION resistance of Aluminum (Al) in $3.5 \% \mathrm{NaCl}$ was improved after surface mechanical attrition treatment (SMAT). Cyclic potentiodynamic polarization (CPP) measurements have shown hysteresis's loop area owing to localized attack. Surface examinations using scanning electron microscopy (SEM), electron dispersive X-ray (EDX), X-ray diffraction (XRD) and grazing induced $\mathrm{X}$-ray diffraction (GIXRD) have been used to investigate changes of composition on the surface at different depths. The result of polarization shows that as increasing the time of annealing before 10 min SMAT the surface of $\mathrm{Al}$ becomes more resistance and behaves similar to that of adding cathodic inhibitor. The study was carried out also for the annealed samples after different time of SMAT 0, 5, 10, 15,20 and $25 \mathrm{~min}$. proved that the corrosion resistance was improved with increasing the time till 15 min treatment and decreased again after that. CPP experiments at all the time except at 15 min SMAT recorded the formation of different steps at different potential after the corrosion potential. The steps are similar to that recorded due to formation of protective film and the break down due to pitting corrosion. GIXRD proved that the appearance of these steps is due to the formation of different metallic and intermetallic solid solution phases which have different corrosion potential. On the other hand the more corrosion resistance of 15 min SMAT was attributed to the formation of the most anodic phase of $\mathrm{Al}_{39} \mathrm{Cu}_{47}$. The dissolution of the treated SMAT Al in $3.5 \% \mathrm{NaCl}$ are localized attack and mainly intergalvanic corrosion where its rate depends on the defence between the corrosion potential of the phases recorded and the Al substrate.
\end{abstract}

Compounds present in $\mathrm{Al}$ and $\mathrm{Al}$ alloys may be either non-metallic impurities, forming intermetallic compounds or components going into solid solution intergranularly ${ }^{(1)}$. On the other hand, metallic impurities present either as elements or as intermetallic compounds where, the corrosion resistance of $\mathrm{Al}$ depends on its corrosion potential ${ }^{(2)}$. In part 1 of the present work ${ }^{(3)}$, the corrosion resistance of grain refines $\mathrm{Al}$ using surface mechanical attrition treatment (SMAT) in $3.5 \% \mathrm{NaCl}$ was investigated under free condition. The techniques used were open circuit potential and surface examination such as scanning electron microscopy (SEM), electron dispersive X-ray (EDX) and X-ray 
diffraction (XRD) to represent the effect of SMAT on the corrosion resistance of $\mathrm{Al}$. The results proved that the corrosion resistance of $\mathrm{Al}$ is controlled by the time of oxide film formation which depends on different factors such as the grain refinement, the segregation of Fe to the outer surface, the formation of micro cavities and the crystallographic orientation of habit $\mathrm{Al}$ (111) plane phases.

It is well known that ${ }^{(2,4)}$ in the case of commercial Al, a large number of intermetallic compounds may be present in the surface. Accordingly as the escape depth of both of EDX and XRD analysis are far from the surface, it is necessary to examine the surface by anther technique to show the phases formed near to the surface. In the present study, a rapid or accelerated technique of cyclic potentiodynamic polarization is used to show the type of attack occurring during the dissolution of SMAT $\mathrm{Al}$ in $3.5 \% \mathrm{NaCl}$. On the other hand, surface examination such as SIM, EDX and XRD beside GIXRD techniques was used to elucidate the effect of different phases formed at different depths, far from and near to the surface, on the corrosion resistance.

\section{Materials and Methods}

The material used in this study was a commercial aluminum sheet and the nominal chemical composition was described in part $1^{(3)}$. The corrosion studies of $\mathrm{Al}$ samples in $3.5 \% \mathrm{NaCl}$ were performed by potentiodynamic cyclic polarization test. The measurements were carried out using a PS6 Meinsberger Potentiostat/Galvanostat, Germany.

Electrochemical experiments were carried out in a conventional three electrode cylindrical Pyrex glass cell with a platinum counter electrode, a saturated calomel electrode (SCE) as a reference electrode and working electrode. Before polarization measurements, the sample was kept at $-1500 \mathrm{mV}$ versus saturated electrode for $20 \mathrm{~min}$ in the test solution to reduce the preimmersion oxide on the sample surface. The potentiodynamic cyclic polarization test was carried out by scanning the electrode potential from -1500 $\mathrm{mV}$ to $+500 \mathrm{mV}$ using a scanning rate of $1 \mathrm{mV} / \mathrm{Sec}$ and reversed again to the backward direction with the same scan rate. Current- time tests were achieved by the application of a constant potential value for a certain time period.

Details of the surface analysis techniques, surface pretreatment and other experimental methods were described elsewhere ${ }^{(5)}$.

\section{Results and Discussion}

\section{Electrochemical measurement}

Figure 1 presents the polarization behaviour of $\mathrm{Al}$ in $3.5 \% \mathrm{NaCI}$ solution with different time of pre-annealing at the same time of SMAT. It is clear from the results presented in Fig. 1 that the corrosion potential $\left(\mathrm{E}_{\mathrm{corr}}\right)$ is shifted towards negative values as the time of pre-annealing is increased. The most negative shift in $\mathrm{E}_{\text {corr }}$ is associated with the lowest cathodic and anodic corrosion current. This indicates that as increasing the time of pre-annealing before $10 \mathrm{~min}$

Egypt. J. Chem. 59, No. 4 (2016) 
SMAT, the surface becomes more resistant and behaves similar to that of adding cathodic inhibitors. It is relevant to mention ${ }^{(6)}$, when a cold worked metal is heated, the energy stored in the metal during the cold working process is released, the dislocation tangles rearrange themselves, and the internal stresses, hardness and strength of the metal are progressively reduced ${ }^{(6)}$.On the other hand, the hall-pitch relation ${ }^{(7-9)}$ reveals that yield strength is inversely proportional to gain size. This confirms that as increasing the time of preannealing at the same temperature of $600^{\circ} \mathrm{C}$ of Fig. 1,SMAT becomes more effective to yield lower gain sizes which improve both of the mechanical properties $^{(10)}$ (strength and wear resistance) and corrosion resistance.

Potentiodynamic polarization measurements are a relatively rapid technique that can give quick and certain answer to corrosion and corrosion problems. Accordingly the effect of SMAT time of 5, 10, 15, 20 and $25 \mathrm{~min}$ on the dissolution of $\mathrm{Al}$ in $3.5 \% \mathrm{NaCl}$ was studied, Fig. 2. It is clear from Fig. 2(a) that: none of these curves exhibited any active-passive transition. This is in agreement with previously published data which represent that, Al can form a protective passive film in air before treatment ${ }^{(11,12)}$. $\mathrm{E}_{\text {corr }}$ of the cold worked $\mathrm{Al}$ (zero) (Fig. 2 a) was shifted to more negative potential after annealing (blank) (Fig. 2 b) from the value of -800 to-1060 in $3.5 \% \mathrm{NaCl}$, respectively. By contrast, $\mathrm{E}_{\text {corr }}$. were displaced to a less negative (anodic) direction by increasing the time of SMAT and a maximum shift was recorded after 15 min SMAT as shown in Fig. 2(d). The shift recorded in $\mathrm{E}_{\text {corr }}$ can be explained as being a result of decreasing the grain size to become more refined as confirmed previously ${ }^{(3)}$.

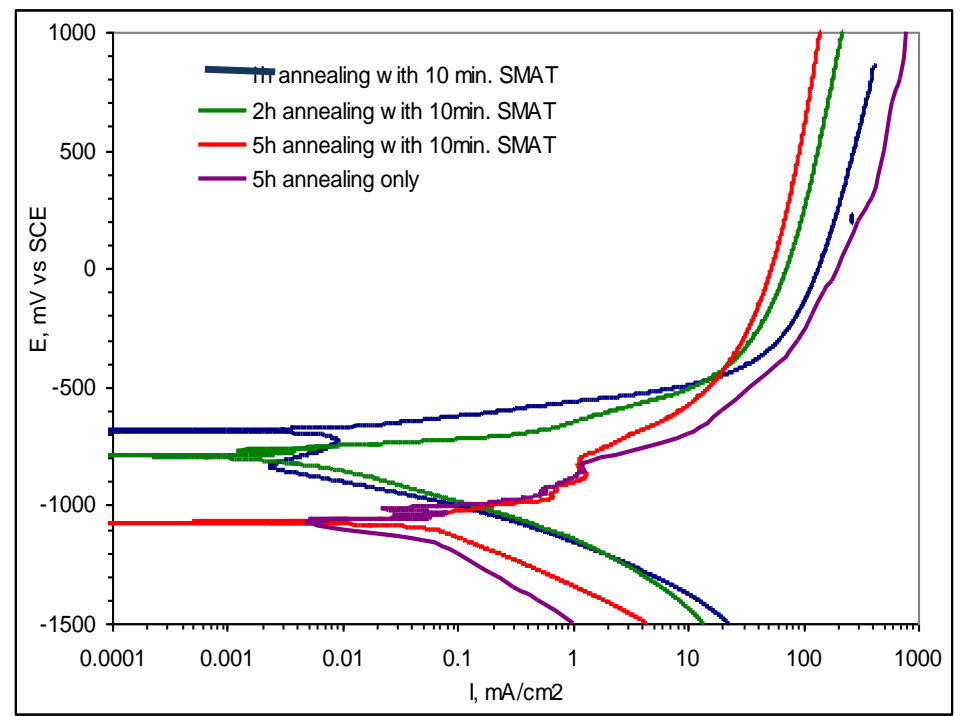

Fig. 1. Potentiondynamic polarization curves of $\mathrm{Al}$ in $3.5 \% \mathrm{NaCl}$ in different time of pre-annealing after $10 \mathrm{~min}$ of SMAT. 

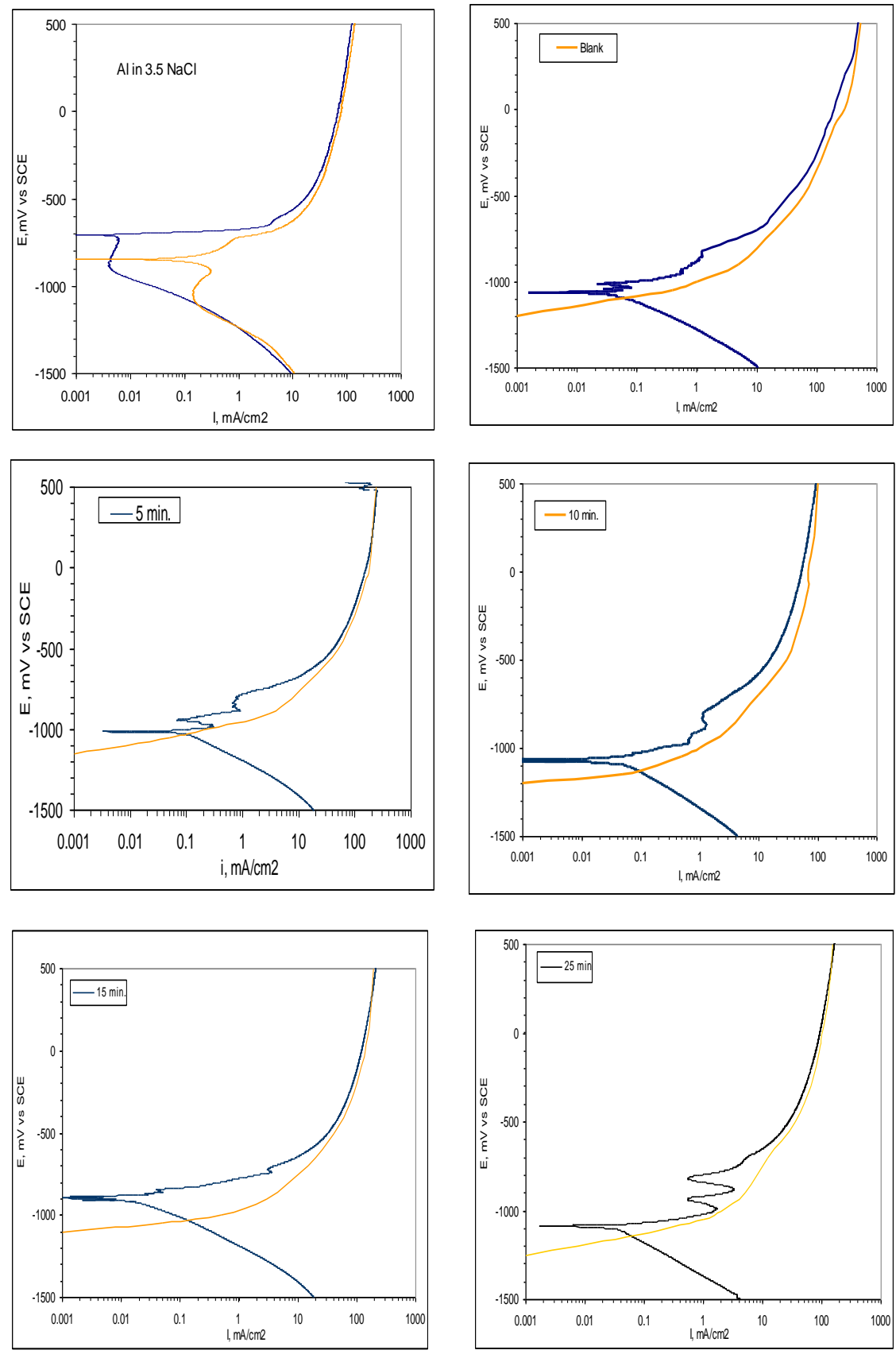

Fig. 2. CPP curves of $\mathrm{Al}$ in $3.5 \% \mathrm{NaCl}$ at different time of SMAT.

Egypt. J. Chem. 59, No. 4 (2016) 
In contradiction, by increasing the time of SMAT to 20 and $25 \mathrm{~min}, \mathrm{E}_{\text {corr }}$ returned to more negative value which increased again to become higher than that recorded in case of zero SMAT (blank). This behaviour occurs as a result of two factors, the first one is due to the increase in the number of accumulated micro-vacancies which are weak points where attack may initiate. While the second factor is related to the increase in the percentage of Fe specially at the white spots which forms a micro galvanic corrosion with Al substrate ${ }^{(3)}$.

A previous work of the potentiostatic polarization of $\mathrm{Al}$ in different concentration of $\mathrm{NaCl}$ from $10^{-5}$ to $10^{-1} \mathrm{M}$ has shown that at diluted concentration up to $10^{-2} \mathrm{M} \mathrm{NaCl}$ after the $\mathrm{E}_{\text {corr }}$ has been attained within a few millivolts, a breakdown of passivity occurred. They concluded that corrosion of $\mathrm{Al}$ and $\mathrm{Al}-\mathrm{Cu}$ alloys in $\mathrm{NaCl}$ progresses by pitting and $\mathrm{E}_{\text {pit }}$ shifted to more negative potential values as increasing the concentration of $\mathrm{NaCl}$.

It can be observed from all curves of Fig. 2 that after the $E_{\text {corr }}$ some steps were recorded which are similar to those recorded due to the formation of protective or passive film and those breakdown due to pitting corrosion. This is in agreement with the previous studies for three reasons, the first one is related to the formation of hysteresis loop after CPP measurements as represented in Fig. 2. The second reason is related to the previous study ${ }^{(11)}$ at the same concentration of $\mathrm{NaCl}$ which concluded that $\mathrm{E}_{\text {corr }}$ was the same as the pitting potential $\left(\mathrm{E}_{\mathrm{pit}}\right)\left(\mathrm{E}_{\mathrm{pit}}\right.$ and $\mathrm{E}_{\text {corr }}$ coincide). While the third one is related to the appearance of these steps at definite values of potential as represented in Table 1. This table shows the variation of the $\mathrm{E}_{\text {corr }}\left(\mathrm{E}_{\mathrm{pit}}\right)$ and the potential of the different steps present as a function of time of SMAT. By increasing the time of SMAT, $\mathrm{E}_{\text {corr }}$ was shifted to less negative potential and the second step after $\mathrm{E}_{\text {corr }}$ became the new $\mathrm{E}_{\text {corr }}$. This occured till 10 min SMAT while at 15 min SMAT only $E_{\text {corr }}$ was recorded at the more anodic value of potential of $-760 \mathrm{mV}$, (Table 1) and there is no any another steps recorded. On increasing the time of SMAT to20 and 25 min., $E_{\text {corr }}$ were shifted again to more negative values and the steps recorded at 5 and $10 \mathrm{~min}$ appeared again.

It was found that, it is difficult to calculate the corrosion rate by means of polarization from Tafel slop or resistance polarization due to the appearance of the different steps which gives higher error in the results. In consequence, it was of interest to give another fact to represent the effect of SMAT time on the corrosion resistance from the electrochemical view through calculation of the current densities at constant value of potential after both of $\mathrm{E}_{\text {corr }}$ and the different steps recorded. A potential of zero $\mathrm{mV}$ was selected to clarify what about the effect of SMAT on the corrosion resistance. It was found from Table 1 that, the current density recorded at $5 \mathrm{~min}$ SMAT is $140 \mathrm{~mA} / \mathrm{cm}^{2}$ which decreased by time to become in smallest value of $30 \mathrm{~mA} / \mathrm{cm}^{2}$ at $15 \mathrm{~min}$ SMAT. Further increase in the SMAT to 20 and $25 \mathrm{~min}$, the current density increases again to become 70 and $100 \mathrm{~mA} / \mathrm{cm}^{2}$, respectively. 
To confirm the CPP result, current density against time measurement for preannealing $\mathrm{Al}$ before (blank) and after different time of 5,10, 15, 20 and 25 SMAT were studied in $3.5 \% \mathrm{NaCl}$ at constant value of $-800 \mathrm{mV}$. This value was chosen from the polarization curves of Fig. 2 where at blank, 5, 10, 20 and 25 min SMAT this value is recorded at the anodic branch while the same value of -800 at 15 min SMAT is within the cathodic branch. The current- time curves of Fig. 3 show that, initial current densities begin at higher values which decrease to reach nearly a steady state and contain some oscillations. This oscillation may be due to the dissolution and reformation of a corrosion product and or initiation and repassivation of some localized attack depending on the time of SMAT as represented in Fig. 3. Figure 3 shows that in case of blank sample the current density recorded after $60 \mathrm{~min}$ is $2.75 \mathrm{~mA}$ and as the time of SMAT is increased up to $15 \mathrm{~min}$ considerably large decrease in current density is recorded and a maximum decrease to $0.1 \mathrm{~mA}$ is recorded after $15 \mathrm{~min}$ SMAT. After that, at 20 and 25 min SMAT the current density increases again to show 2 and $1.75 \mathrm{~mA}$, respectively. This supports the conclusion reported previously in CPP of Fig. 2 which represents the higher corrosion resistance of 15 min SMAT. To complete the picture it is necessary to examine the surface of the sample before and after electrochemical measurements.

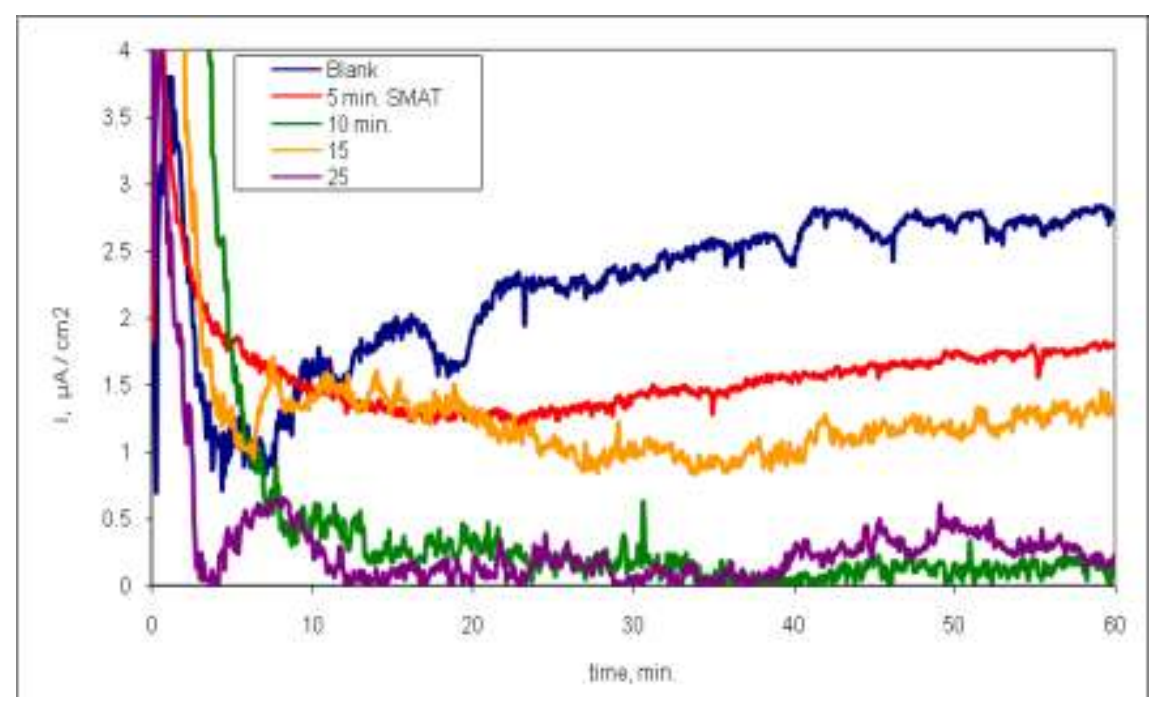

Fig. 3. Current -time curves for $\mathrm{Al}$ in $3.5 \% \mathrm{NaCl}$ in different time of SMAT at constant value of potential $(-800 \mathrm{mV})$. 
TABLE 1. $E_{\text {corr, }}$ the potential of the different steps present and $I\left(\mathrm{~mA} / \mathrm{cm}^{2}\right)$ at zero $(\mathrm{mV})$ as a function of time SMAT.

\begin{tabular}{|c|c|c|}
\hline Sample Treatment & $\begin{array}{c}\mathbf{E}_{\text {Corr. }} \text { and the potential of } \\
\text { different steps present }(\mathbf{m V})\end{array}$ & $\begin{array}{c}\mathbf{I}\left(\mathbf{m A} / \mathbf{c m}^{2}\right) \text { recorded at zero } \\
\mathbf{m V}\end{array}$ \\
\hline Cold worked(0) & $-700,-640$ & 70 \\
\hline Annealing only & $-1065,-1015,-930$ and -810 & 90 \\
\hline 5 min. & $-1010,-940$ and -820 & 140 \\
\hline 10 min. & $-920,-760$ & 90 \\
\hline $15 \mathrm{~min}$. & -890 & $\mathbf{7 0}$ \\
\hline $20 \mathrm{~min}$. & $-1100,-940,-820$ & $\mathbf{1 0 0}$ \\
\hline $25 \mathrm{~min}$. & $-1090,-930,-810$ & 80 \\
\hline
\end{tabular}

Surface analysis measurements

It was of interest to examine the surface of $\mathrm{Al}$ sample after SMAT before and after immersed in $3.5 \% \mathrm{NaCl}$ for 120 min using different surface analysis techniques such as EDX, GIXRD and SEM

\section{EDX analysis}

As recorded in part $1^{(3)}$ it is necessary to mention that the SEM examination after immersion of SMAT Al for all time of 5, 10, 15, 20 and $25 \mathrm{~min}$ in 3.5\% $\mathrm{NaCl}$ shows the appearance of a bright spot at a specific sites on the surface. On the other hand, the EDX analysis concluded that Fe was detected with a small ratio overall the surface in comparison with the higher ratio recorded at the bright regions.

In this study, the EDX analysis of Table 2 represent the effect of SMAT time on the changes of the surface composition of $\mathrm{Al}$ before and after treatment in $3.5 \% \mathrm{NaCl}$ for $120 \mathrm{~min}$. It was found from Table 2 that, the ratio of $\mathrm{Fe}$ is bigger after immersion than that recorded before immersion either at the whole surface or at the bright $\mathrm{Fe}$ spots. This shows that also $\mathrm{NaCl}$ accelerates the segregation rate of Fe to the outer surface beside SMAT effect. 
TABLE 2. EDX analysis of SMAT time of Al before and after treatment in $3.5 \%$ $\mathrm{NaCl}$ for $120 \mathrm{~min}$.

\begin{tabular}{|c|c|c|c|c|c|c|c|c|c|c|c|c|}
\hline \multirow{3}{*}{$\begin{array}{c}\text { Time } \\
\text { of } \\
\text { SMAT } \\
\text { (min.) }\end{array}$} & \multicolumn{6}{|c|}{$\begin{array}{c}\text { Over the major part of the surface } \\
\text { (at \%) }\end{array}$} & \multicolumn{6}{|c|}{ In the white regions (at \%) } \\
\hline & \multicolumn{3}{|c|}{$\begin{array}{c}\text { Before } \\
\text { treatment in } \\
3.5 \% \mathrm{NaCl}\end{array}$} & \multicolumn{3}{|c|}{$\begin{array}{c}\text { after treatment in } \\
3.5 \% \mathrm{NaCl}\end{array}$} & \multicolumn{3}{|c|}{$\begin{array}{l}\text { Before treatment } \\
\text { in } 3.5 \% \mathrm{NaCl}\end{array}$} & \multicolumn{3}{|c|}{$\begin{array}{c}\text { after treatment in } \\
3.5 \% \mathrm{NaCl}\end{array}$} \\
\hline & $\mathbf{O}$ & Al & $\mathbf{F e}$ & $\mathbf{O}$ & Al & $\mathbf{F e}$ & $\mathbf{O}$ & Al & $\mathbf{F e}$ & $\mathbf{O}$ & Al & $\mathbf{F e}$ \\
\hline blank & 7.5 & 92.5 & --- & 15.8 & 84.2 & --- & 7.8 & 89.4 & 2.8 & 10.76 & 82.32 & 6.7 \\
\hline 5 & 9.5 & 91.5 & --- & 17.5 & 82.0 & 0.5 & 8.2 & 88.4 & 3.4 & 12.2 & 74.3 & 13.5 \\
\hline 10 & 12 & 88 & --- & 19.66 & 79.8 & 0.54 & 9.2 & 80.3 & 10.15 & 14.5 & 62.11 & 23.39 \\
\hline 15 & 12.5 & 87 & 0.5 & 28.29 & 70.71 & 1 & 10.2 & 74.4 & 15.3 & 16.2 & 41.08 & 42.72 \\
\hline 20 & 12.2 & 85.3 & 2.5 & 15.2 & 80.6 & 4.2 & 4 & 87.6 & 8.4 & 22.3 & 59.2 & 18.5 \\
\hline 25 & 10 & 84.8 & 5.2 & 13.1 & 80.4 & 6.5 & 3 & 83.6 & 13.4 & 22.73 & 50.4 & 26.88 \\
\hline
\end{tabular}

GIXRD technique

In the light of the above results recorded in part $1^{(3)}$ where XRD of higher escape depth examination is used, it was necessary to study and examine the surface of SMAT Al before and after immersion in $3.5 \% \mathrm{NaCl}$ using (GIXRD) analysis technique to show the phases formed near to the surface. Table 3 shows that after 5 min SMAT without immersion in $3.5 \% \mathrm{NaCl}$, the measured composition of the surface represented the appearance of intermetallic solid solution phases of $\mathrm{Al}_{4} \mathrm{Cu}_{9}$ and $\mathrm{Al}_{1} \mathrm{Ti}_{1}$ beside $\mathrm{Si}$ and $\mathrm{Al}$ metallic phases. These phases disappeared after treatment in $3.5 \% \mathrm{NaCl}$ and the phases recorded are metallic $\mathrm{Al}$ and traces of intermetallic $\mathrm{Cu}_{3} \mathrm{Al}$ only. The appearance of $\mathrm{NaCl}$ phase is due to the contamination from solution. In generally all the phases were recorded with different plane of orientation and different structure. Increasing the SMAT time to $10 \mathrm{~min}$, the surface of the untreated sample exhibited the formation of $\mathrm{Al}_{1} \mathrm{Fe}_{3}, \mathrm{Al}_{4} \mathrm{Cu}_{9}$ and $\mathrm{Al}_{10} \mathrm{O}_{16}$ solid solution phases and the elemental Si phase only with different plane orientation and structures. After treatment in $3.5 \% \mathrm{NaCl}$ for 120 min only $\mathrm{Al}$ was detected.

On increasing the SMAT time to $15 \mathrm{~min}$, the detected phases containing elemental phases of $\mathrm{Si}, \mathrm{Al}, \mathrm{Fe}, \mathrm{Ti}$ with a very small ratio of only $\mathrm{Al}_{10} \mathrm{Cu}_{0 \cdot 01}$ solid solution for the untreated sample. The treated sample of 15min SMAT in $3.5 \% \mathrm{NaCl}$ recorded mainly $\mathrm{AL}_{35} \mathrm{Cu}_{47}$ of different planes and a small ratio of elemental Al, Si phases. As mentioned previously these phases are different from those recorded with the lower SMAT time. 
Improving Corrosion Resistance of Al through Sever Plastic Deformation 2565

TABLE 3. GIXRD pattern identification Al sheets after SMAT of different times from 5 to 25 min (a) after and (b) befor treatment in $3.5 \% \mathrm{NaCl}$ for $120 \mathrm{~min}$.

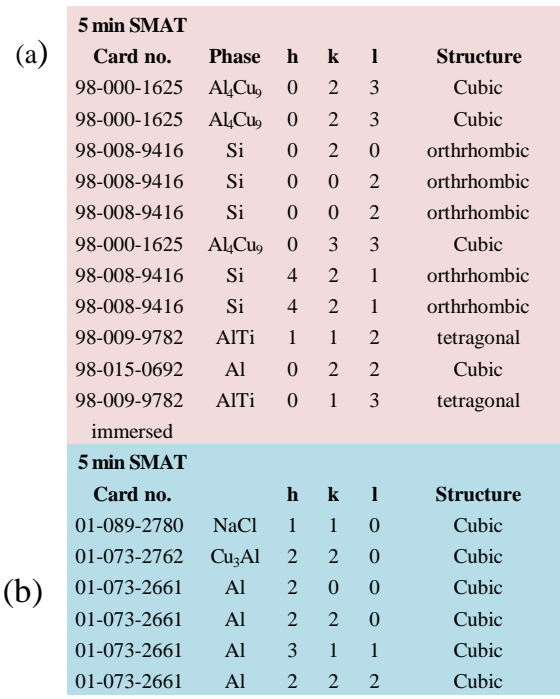

(a)

\begin{tabular}{|c|c|c|c|c|c|}
\hline \multicolumn{6}{|l|}{15 min SMAT } \\
\hline Card no. & Phase & $\mathbf{h}$ & & & Structure \\
\hline $98-008-9416$ & 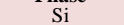 & 0 & 0 & 2 & orthorhomic \\
\hline $98-015-0692$ & $\mathrm{Al}$ & 1 & 1 & 1 & Cubic \\
\hline $98-008-9416$ & $\mathrm{Si}$ & 1 & 1 & 2 & orthorhomic \\
\hline 98-006-4795 & $\mathrm{Fe}$ & 0 & 1 & 1 & Cubic \\
\hline 98-008-9416 & $\mathrm{Si}$ & 2 & 2 & 0 & orthorhomic \\
\hline $98-004-1503$ & $\mathrm{Ti}$ & 0 & 0 & 2 & Cubic \\
\hline $98-010-7774$ & $\mathrm{Al}_{0.99} \mathrm{Cu}_{0.01}$ & 0 & 0 & 2 & Cubic \\
\hline $98-006-4795$ & $\mathrm{Fe}$ & 0 & 0 & 2 & Cubic \\
\hline $98-015-0692$ & $\mathrm{Al}$ & 0 & 2 & 2 & Cubic \\
\hline $98-004-1503$ & $\mathrm{Ti}$ & 0 & 2 & 2 & Cubic \\
\hline $98-008-9416$ & $\mathrm{Si}$ & 5 & 1 & 1 & orthorhomic \\
\hline $98-015-0692$ & $\mathrm{Al}$ & 1 & 1 & 3 & Cubic \\
\hline $98-004-1503$ & $\mathrm{Ti}$ & 1 & 1 & 3 & Cubic \\
\hline $98-004-1503$ & $\mathrm{Ti}$ & 1 & 1 & 3 & Cubic \\
\hline $\begin{array}{c}98-004-1503 \\
\text { immersed }\end{array}$ & $\mathrm{Ti}$ & 1 & 1 & 3 & Cubic \\
\hline \multicolumn{2}{|l|}{$\begin{array}{c}\text { immersed } \\
15 \mathrm{~min} \text { SMAT }\end{array}$} & & & & \\
\hline $98-24-0196$ & A & 2 & 4 & & orthorhombic \\
\hline $98-24-0196$ & $\mathrm{Al}_{35,472} \mathrm{Cu}_{47.792}$ & 0 & 2 & 4 & orthorhombic \\
\hline 98-24-0196 & $\mathrm{Al}_{35.472} \mathrm{Cu}_{47.792}$ & 0 & 2 & 4 & orthorhombic \\
\hline $98-005-3775$ & $\mathrm{Al}$ & 1 & 1 & 1 & Cubic \\
\hline $98-24-0196$ & $\mathrm{Al}_{35,472} \mathrm{Cu}_{47.792}$ & 2 & 6 & 0 & orthorhombic \\
\hline $98-008-9416$ & $\mathrm{Si}^{4{ }^{4}}$ & 2 & 2 & 0 & orthorhombic \\
\hline 98-24-0196 & $\mathrm{Al}_{35.472} \mathrm{Cu}_{47.792}$ & 4 & 0 & 0 & orthorhombic \\
\hline 98-24-0196 & $\mathrm{Al}_{35.472} \mathrm{Cu}_{47.792}$ & 4 & 4 & 4 & orthorhombic \\
\hline 98-24-0196 & $\mathrm{Al}_{35.472} \mathrm{Cu}_{47.792}$ & 4 & 4 & 4 & orthorhombic \\
\hline $98-24-0196$ & $\mathrm{Al}_{35,472} \mathrm{Cu}_{47.792}$ & 4 & 4 & 4 & orthorhombic \\
\hline $98-24-0196$ & $\mathrm{Al}_{35,472} \mathrm{Cu}_{47,792}$ & 4 & 4 & 4 & orthorhombic \\
\hline $98-24-0196$ & $\mathrm{Al}_{35,472} \mathrm{Cu}_{47,792}$ & 4 & 4 & 4 & orthorhombic \\
\hline $98-24-0196$ & $\begin{array}{l}\mathrm{Al}_{35.472} \mathrm{Cu}_{477.792} \\
\text { (2) }\end{array}$ & 0 & 2 & 8 & orthorhombic \\
\hline $98-24-0196$ & $\mathrm{Al}_{35.472} \mathrm{Cu}_{47.792}$ & 6 & 4 & 2 & orthorhombic \\
\hline $98-24-0196$ & $\mathrm{Al}_{35,472} \mathrm{Cu}_{47,792}$ & 1 & 9 & & orthorhombic \\
\hline $98-24-0196$ & 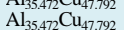 & 1 & 9 & 5 & orthorhombic \\
\hline $98-24-0196$ & $\mathrm{Al}_{35,472} \mathrm{Cu}_{47,792}$ & 1 & 9 & 5 & orthorhombic \\
\hline $98-24-0196$ & $\begin{array}{l}\mathrm{Al}_{35.472} \mathrm{Cu}_{47.7792} \\
\end{array}$ & 3 & 3 & 7 & orthorhombic \\
\hline 98-24-0196 & $\mathrm{Al}_{35,472} \mathrm{Cu}_{47.792}$ & 3 & 3 & 7 & orthorhombic \\
\hline $98-24-0196$ & $\mathrm{Al}_{35,472} \mathrm{Cu}_{47,792}$ & 2 & 2 & 8 & orthorhombic \\
\hline 98-24-0196 & $\begin{array}{l}\mathrm{Al}_{35.472} \mathrm{Cu}_{47.792} \\
\end{array}$ & 6 & 6 & 0 & orthorhombic \\
\hline $98-24-0196$ & $\mathrm{Al}_{35.472} \mathrm{Cu}_{47.792}$ & 6 & 2 & 4 & orthorhombic \\
\hline & $\mathrm{Al}_{35,472} \mathrm{Cu}_{47.792}$ & 6 & 2 & 4 & orthorhombic \\
\hline $98-24-0196$ & $\mathrm{Al}_{354722} \mathrm{Cu}_{47792}$ & 6 & 2 & 4 & orthorhombic \\
\hline $98-005-3775$ & $\mathrm{Al}$ & 2 & 2 & 2 & Cubic \\
\hline $98-005-3775$ & $\mathrm{Al}$ & 2 & 2 & 2 & Cubic \\
\hline $98-005-3775$ & $\Delta$ & 2 & 2 & 2 & Cubic \\
\hline
\end{tabular}

(a)

$\begin{array}{cccccc}\begin{array}{c}\text { 10 min SMAT } \\ \text { Card no. }\end{array} & \mathrm{Phase} & \mathbf{h} & \mathbf{k} & \mathbf{I} & \text { Structure } \\ 98-060-7484 & \mathrm{Al}_{1} \mathrm{Fe}_{3} & 0 & 0 & 2 & \text { cubic } \\ 98-015-1371 & \mathrm{Al}_{4} \mathrm{Cu}_{9} & 0 & 2 & 3 & \text { cubic } \\ 98-015-1371 & \mathrm{Al}_{4} \mathrm{Cu}_{9} & 0 & 2 & 3 & \text { cubic } \\ 98-008-9415 & \mathrm{Si} & 0 & 2 & 0 & \text { orthrhombic } \\ 98-006-8771 & \mathrm{Al}_{10.66} \mathrm{O}_{16} & 1 & 2 & 1 & \text { tetragonal } \\ 98-006-8771 & \mathrm{Al}_{10.66} \mathrm{O}_{16} & 0 & 1 & 3 & \text { tetragonal } \\ 98-008-9415 & \mathrm{Si} & 3 & 1 & 1 & \text { orthrhombic } \\ 98-008-9415 & \mathrm{Si} & 3 & 1 & 1 & \text { orthrhombic } \\ 98-008-9415 & \mathrm{Si} & 1 & 1 & 2 & \text { orthrhombic } \\ 98-008-9415 & \mathrm{Si} & 2 & 0 & 2 & \text { orthrhombic } \\ 98-008-9415 & \mathrm{Si} & 4 & 2 & 1 & \text { orthrhombic } \\ 98-60-7484 & \mathrm{AlFe}_{3} & 0 & 0 & 4 & \text { cubic } \\ 98-015-1371 & \mathrm{Al}_{4} \mathrm{Cu}_{9} & 2 & 3 & 6 & \text { cubic } \\ 98-015-1371 & \mathrm{Al}_{4} \mathrm{Cu}_{9} & 0 & 5 & 5 & \text { cubic } \\ 98-015-1371 & \mathrm{Al}_{4} \mathrm{Cu}_{9} & 0 & 5 & 5 & \text { cubic } \\ 98-015-1371 & \mathrm{Al}_{4} \mathrm{Cu}_{9} & 3 & 3 & 6 & \text { cubic } \\ \text { immersed } & & & & & \\ \text { 10 min SMAT } & & & & & \\ 01-071-4625 & \mathrm{Al} & 1 & 1 & 1 & \text { cubic } \\ 01-071-4625 & \mathrm{Al} & 1 & 1 & 1 & \text { cubic } \\ 01-071-4625 & \mathrm{Al} & 2 & 0 & 0 & \text { cubic } \\ 01-071-4625 & \mathrm{Al} & 2 & 2 & 0 & \text { cubic } \\ 01-071-4625 & \mathrm{Al} & 3 & 1 & 1 & \text { cubic } \\ 01-071-4625 & \mathrm{Al} & 2 & 2 & 2 & \text { cubic }\end{array}$

25 min SMAT

(a) Card no. phase $\quad h \quad k \quad l \quad$ Structure 98-003-2633 $\quad \mathrm{AlCuO}_{2} \quad 0 \quad 1 \quad 2$ hexagonal 98-005-7667 $\quad \mathrm{Al}_{2} \mathrm{C}_{3.4} \quad 0 \quad 1 \quad 2 \quad$ hexagonal 98-015-0692 $\quad \mathrm{Al} \quad 0 \quad 0 \quad 2 \quad$ cubic 98-005-7667 $\quad \mathrm{Al}_{2} \mathrm{C}_{3.4} \quad 0 \quad 2 \quad 2 \quad$ hexagonal 98-015-0692 $\quad \mathrm{Al} \quad 0 \quad 2 \quad 2 \quad$ cubic

(b) immersed

25 min SMAT

98-015-0692 $\quad \mathrm{Al} \quad 1 \quad 1 \quad 1 \quad$ cubic 98-015-0692 $\quad \mathrm{Al} \quad 0 \quad 0 \quad 2 \quad$ cubic 98-015-0692 Al $0 \begin{array}{llll}0 & 2 & \text { cubic }\end{array}$ 98-024-0129 Al $0 \begin{array}{llll} & 2 & 2 & \text { cubic }\end{array}$ 01-089-9056 $\quad \mathrm{Si} \quad 5 \quad 1 \quad 1 \quad$ orthorhombic 00-003-0932 Al $2 \quad 2 \quad 0 \quad$ cubic 00-003-0932 Al $\quad 2 \quad 2 \quad 0 \quad$ cubic 98-015-0692 $\quad \mathrm{Al} \quad 1 \quad 1 \quad 3 \quad$ cubic 98-024-0129 $\quad \mathrm{Al} \quad 1 \quad 1 \quad 3 \quad$ cubic 00-003-0932 $\quad \mathrm{Al} \quad 3 \quad 1 \quad 1 \quad r \quad$ cubic

Egypt. J. Chem. 59, No. 4 (2016) 
Further increasing in the SMAT time to 20 and 25 min before treatment in $3.5 \%$ $\mathrm{NaCl}$, two solid solution phases of $\mathrm{AlCuO}_{2}$ and $\mathrm{Al}_{2} \mathrm{Cu}_{3.4}$ beside only elemental phase of $\mathrm{Al}$ were detected. After treatment in $3.5 \% \mathrm{NaCl}$ the surface composition revealed that there is no phases of intermetallic solid solution and $\mathrm{Al}$ is the mostly phase recorded over the surface with a very small amount of Si phase .

From the above results, we can conclude that at all the time of SMAT except at $15 \mathrm{~min}$ three features are recorded. First, before treatment in $3.5 \% \mathrm{NaCl}$ different types of solid solution phases with a lower concentration of elemental $\mathrm{Al}$ and $\mathrm{Si}$ phase were detected. Second $\mathrm{Al}$ and $\mathrm{Si}$ are the only phases detected. The last feature recorded about the structures which distributed between cubic, orthorhombic and tetragonal with different plane of orientations. In contradiction, at $15 \mathrm{~min}$ SMAT, the surface composition shows mainly a different phase of elemental $\mathrm{Si}, \mathrm{Fe}$ and $\mathrm{Ti}$ before treatment in 3.5\% $\mathrm{NaCl}$. Also, after treatment the recorded composition is mainly $\mathrm{Al}_{39} \mathrm{Cu}_{47}$ phase.

These conclusions confirm the above results of potentiodynamic polarization curves of Fig. 2, where: At all the SMAT time except 15 min the polarization curves show that, after $\mathrm{E}_{\text {corr }}$ different steps appeared. This was attributed to the formation of different intermetallic solid solution as shown in Table 3. It is well known that intermetallic particles in aluminum alloys may be either anodic or cathodic to the matrix. Accordingly, two main types of local attack are formed; one of them appears around a more or less particle potential and the attack is occurring mainly in the matrix. This type is called localized galvanic corrosion of the more active matrix (anodic) promoted by the more noble (cathodic) particle. While the second type of local attack is often deep which occurs as a result of particles fallout, selective dissolution of the electrochemically active particles or as in the case of some $\mathrm{Cu}$-bearing particles, particle dealloying and non-faradaic liberation of the $\mathrm{Cu}$ component?

On the other hand, also at 15 min SMAT, Fig. 2(d) shows that no steps are recorded after $E_{\text {corr }}$ consistent with the surface composition of the untreated sample where the metallic phase of $\mathrm{Al}, \mathrm{Si}$, small amount of Fe and $\mathrm{Ti}$ were only detected with a very traces amount of $\mathrm{Al}_{10} \mathrm{Cu}_{0.01}$ phase. The appearance of small amount of $\mathrm{Fe}$ and traces of $\mathrm{Al}_{10} \mathrm{Cu}_{0 \cdot 01}$ phases is responsible for the non-detection of the steps in Fig. 2(d) where the potential difference between $\mathrm{Al}$ and both of $\mathrm{Si}$ and $\mathrm{Ti}$ is very small. On the other hand the surface of the treated sample in $3.5 \%$ $\mathrm{NaCl}$ of 15 min SMAT represents mainly the formation of $\mathrm{Al}_{35} \mathrm{Cu}_{47}$ phase which is behind the shift in $\mathrm{E}_{\text {corr }}$ to more anodic $(-740 \mathrm{mV})$ and also the disappearance of the previous steps recorded.

\section{SEM}

In order to conform the effect of formation of the above mentioned phases on the corrosion behaviour of Al, the SEM image of Fig. 4 was taken at potential of zero $\mathrm{mV}$ of Fig. 2 which was recorded after 10 min SMAT. The micrograph of

Egypt. J. Chem. 59, No. 4 (2016) 
Fig. 4 reveals that the surface had a cluster of $\mathrm{Fe}$, where the EDX analysis represent 23.39 at \%of Fe. The appearance of the local attack around the cluster confirms that the phases formed are more resistance than the Al substrate and the hysteresis loop recorded in Fig. 2 is not due to the pitting corrosion only but also due to the intergalvanic attack which is formed as a result of the potential difference between the cluster of $\mathrm{Fe}$ and $\mathrm{Al}$ substrate.

To understand the dissolution of these phases, it is necessary to mention that (13) the dissolution of $\theta$ phase of $\mathrm{Al}_{2} \mathrm{Cu}$ which formed due to the enrichment of $\mathrm{Cu}$ on $\mathrm{Al}$ surface by a simple dealloying mechanism of

$$
\mathrm{Al}_{2} \mathrm{Cu} \rightarrow 2 \mathrm{Al}^{+++}+\mathrm{Cu}+6 \mathrm{e}
$$

This occurs at potential more active than the $\mathrm{Cu}$ reversible potential. Others ${ }^{(12,14,15)}$ supported the view that the dissolution involves firstly the dealloying of intermetallic compound particle of $\theta \mathrm{Al}_{2} \mathrm{Cu}$ as

$$
\begin{array}{lll}
\mathrm{Al}_{2} \mathrm{Cu} & \rightarrow & 2 \mathrm{Al}^{+++}+\mathrm{Cu}^{++}+8 \mathrm{e} \\
\mathrm{Cu}^{++}+2 \mathrm{e} & \rightarrow & \mathrm{Cu}
\end{array}
$$

Secondly, metallic $\mathrm{Cu}$ clusters were isolated mechanically and electrically by physical coarsening of the dealloyed particles. Others ${ }^{(16)}$ found that the dissolution of $\mathrm{Cu}$ occurs as a result of the galvanic couples due to cathodic reaction with $\mathrm{Al}$ alloy to produce $\mathrm{Al}^{+++}$and $\mathrm{Cu}^{++}$. Another work by the present author reported previously ${ }^{(11,12)}$ that the $\mathrm{Cu}$ cluster itself go to the solution as a result of the galvanic attack around the cluster itself. Accordingly it can be confidently mentioned therefore that the dissolution of the different phases recorded was due to the above of the four previous mentioned reasons as, the first one occurs by a simple dealloying of the intermetallic compound as in equation (1). The second one occurs by isolating the metallic clusters of $\mathrm{Fe}, \mathrm{Si}$, $\mathrm{Cu} . .$. mechanically and electrically by physical coarsening of the dealloyed particles. The third one is due to the cathodic reaction of the intermetallic compound to produce its cations such as $\mathrm{Al}^{+++}$and $\mathrm{Fe}^{+++}$or $\mathrm{Al}^{+++}$and $\mathrm{Cu}^{++}$and so on. The last reason is occurs as a result of the metallic cluster itself such as $\mathrm{Fe}$, $\mathrm{Cu}, \mathrm{Si}, \ldots$ go to the solution due to the galvanic attack around the cluster itself. 


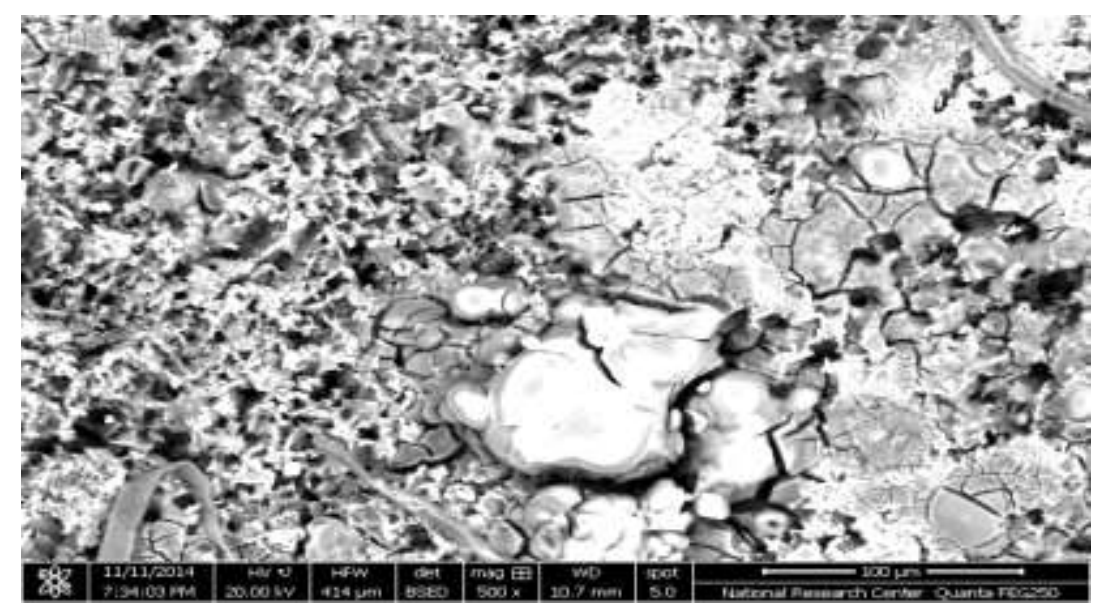

Fig. 4. SEM image showing the surface of Al after $10 \mathrm{~min}$. SMAT at potential of zero $\mathrm{mV}$.

\section{Conclusion}

(a) The results of electrochemical measurement concluded that:

1. In all cases the dissolution of Al occured mainly by localized attack as represented by the appearance of hysteresis loop area in the CPP curves.

2. In all curves of CPP there were no active-passive transition where the corrosion potential was the same as the pitting potential, i.e. $\mathrm{E}_{\mathrm{pit}}$ and $\mathrm{E}_{\text {corr }}$ coincide. On the other hand all the curves except at 15 min SMAT Al the $\mathrm{E}_{\text {corr }}$ recorded the formation of different steps which had different corrosion potential.

3. By increasing the time of annealing at constant the time of SMAT, $\mathrm{E}_{\text {corr }}$ was shifted to more negative potential while both the cathodic and anodic current densities decreased. This indicates that the surface of $\mathrm{Al}$ became more resistance and behaves similar to that of adding cathodic inhibitor.

4. By increasing the time of SMAT of $\mathrm{Al}$ after annealing $\mathrm{E}_{\text {corr }}$ was shifted to less negative potential which recorded a maximum anodic value at $15 \mathrm{~min}$. SMAT and the corrosion rate was decreased by the same manner as represented from I-T measurement. As increasing the time of SMAT to 20 and $25 \mathrm{~min} \mathrm{E}_{\text {corr }}$ were returned again to increase towards the more negative value and the corrosion rate is increased again. These represented that 15 min SMAT is the best time for improving the surface to become more corrosion resistance. (b) The results of surface examination shows that:

1. The EDX analysis concluded that in all cases Fe was detected with a small ratio over the entire surface in comparison with the higher ratio recorded at the bright spots regions. Also, in all cases the ratio of $\mathrm{Fe}$ recorded on the surface after treatment in $3.5 \% \mathrm{NaCl}$ was higher than before. This proved that not only SMAT time affects increasing the segregation of Fe to the outer surface but also the treatment in $3.5 \% \mathrm{NaCl}$ is more effective.

Egypt. J. Chem. 59, No. 4 (2016) 
2. GIXRD technique concluded that the steps recorded during the CPP measurement are controlled by the formation of different metallic and intermetallic solid solution phases. These phases may be either anodic or cathodic to the Al matrix.

3. The effect of the SMAT of Al on the corrosion resistance depends also on the $\mathrm{E}_{\mathrm{corr}}$ of the phases recorded where the dissolution is manly intergranular galvanic corrosion.

\section{References}

1. Wernick, S. and Pinner, R., The Surface Treatment and Finishing of Aluminum and Its Alloys, Second edition, Robert Drapere LTD Teddington, pp.12 (1959).

2. Scamans, G.M., Birbilis, N. and Buchheit, R. G., Corrosion of Aluminum and Its Alloys, Elsevier B.V. (2010).

3. Ebrahim, M. R., El Meleigy, A. E., Abd Elhamid Sh. E. and El Warraky, A.A., Improving corrosion resistance of Al through sever plastic deformation1-under free condition, submitted for publication. Egypt.J.Chem. 59, 4,537-555 (2016).

4. Wernick, S. and Pinner, R., The Surface Treatment and Finishing of Aluminum and Its Alloys, Second edition, Robert Drapere LTD Teddington, , pp.253 (1959).

5. Atta, D., Ebrahim, M.R., Grais, Kh. I., Eid, K. A. and Al-Ashkar, E., Spectroscopic Analysis of Severe Plastically Deformed Raw Al Rolled Sheet, Quantum Matter, 5 ,1-6 (2016) .

6. Procter, R.P.M., Corrosion and Protection Centre, School of Materials, University of Manchester, Manchester M60 1QD UK, 2, pp. 20-94, 20-130, Elsevier B. V.(2010).

7. Ralston, K. D., Birbilis, N. and Davies, C.H.J., Revealing the relationship between grain size and corrosion rate of metals. Scaipta Materialia, 63 , 1201-1204 (2010).

8. Hall , E.O., The Deformation and Ageing of Mild Steel: III Discussion of Results, Proc. Phys. London. B64 , 747 (1951).

9. Petch, N.J., The Cleavage Strength of Polycrystals. J. Iron steel Inst. 174, 25-28 (1953).

10. Ralston, K.D., Fabijanic, D. and Birbilis, N., Effect of grain size on corrosion of high purity aluminums. Electrochimica Acta, 56 , 1729-1736 (2011).

11. Elwarraky, A.A., El-Aziz, A. M. and Soliman, Kh. A., Copper redeposition and surface enrichment during the dissolution of $\mathrm{Al}-\mathrm{Cu}$ alloys in different concentrations 
of $\mathrm{NaCl}$ solution. Part 1-electrochemical measurements. Anti- Corros. Method M, 54(3), 155-16 (2007).

12. El Warraky, A.A., El-Aziz, A. M. and Soliman, Kh. A., Copper redeposition and surface enrichment during the dissolution of Al-Cu alloys in different concentrations of NaClsolution.Part 2 -spectroscopic analysis measurements. Anti-Corros Method M, 54 (3), 163-172 (2007).

13. Mazurkiewicz, B. and Piotrowski, A., The electrochemical behavior of the $\mathrm{Al}_{2} \mathrm{Cu}$ intermetallic compound. Corros. Sci. 23, 697-707 (1983).

14. Buchheit, R. G., Martinez, M. A. and Montes, L.P. "Cu redistribution and surface enrichment due to dissolution of Al-Cu alloys", Localized Corrosion Proceeding of the Research Topical Symposium, Corrosion, NACE, Houston, USA, pp.265 (2001).

15. Buchheit, R. G., Martinez, M.A. and Montes, L.P., Evidence for ion formation by dissolution and dealloying the $\mathrm{Al}_{2} \mathrm{CuMg}$ intermetallic compound in rotating ring-disk collection experiments. J. Electrochem. Soc. 147(1), 119-124 (2001).

16. Obispo, H. M., Murr, L.E., Arrowood, R. M. and Trillo, E.A., Copper deposition during the corrosion of aluminum alloy 2024 in sodium chloride solutions. J. Mat. Sci. $35,3479-3495$ (2000).

(Received 10/5/2016;

accepted 12/6/2016) 


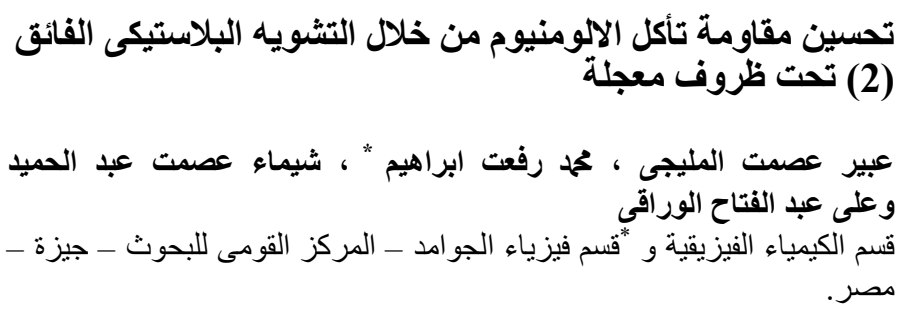

نتيجة تم تحسين معدل تأكل الالومنيوم فى محلول 3.5\% من كلور ايد الصوديوم

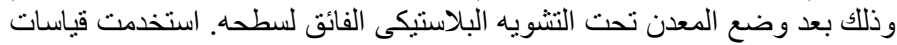

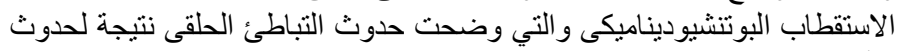

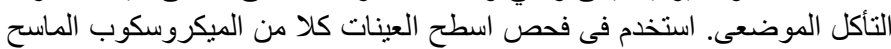

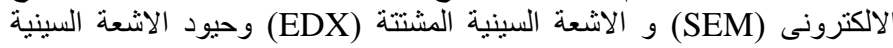

الى جانب حيود الاشعة السينية السطحية (GRD)

الموجودة عند اعماق مختلفة من السطح.

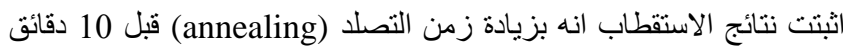

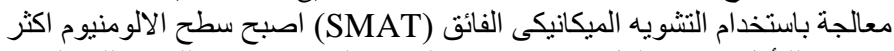

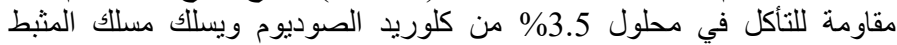

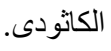

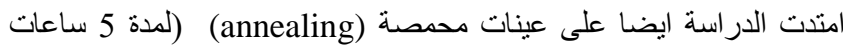

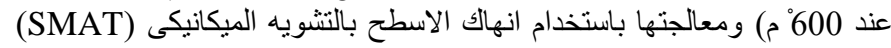

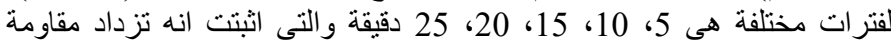
التأكل بزيادة زمن المعالجة حتى 15 دقيقة وبعد ذللك تقل مرة اخرى.

سجلت قياسات الاستقطاب البتنشيوديناميكى خطوات محددة يكون فيها التيار

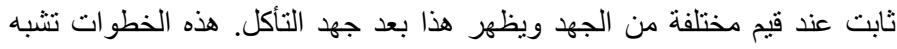

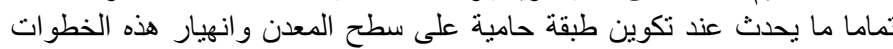

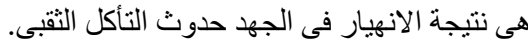

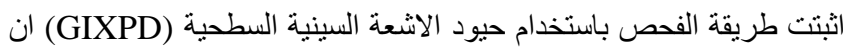

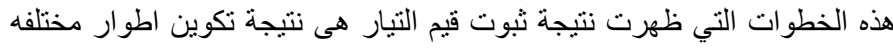

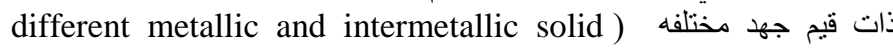
(solution

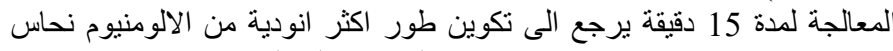

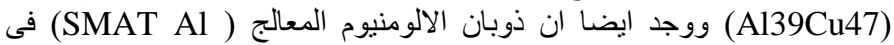

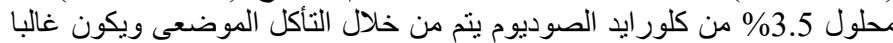

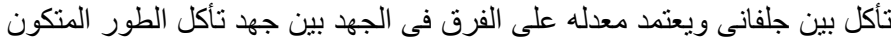
وجهد الالومنيوم نفسـان. 